Sains Malaysiana 48(9)(2019): 1937-1946

http://dx.doi.org/10.17576/jsm-2019-4809-15

\title{
Effect of N-Acetylcysteine Supplementation on Oxidative Stress-Mediated Cryoinjury of Bone Marrow Derived-Hematopoietic Stem Cells
}

(Kesan Suplementasi N-Asetilsistein ke atas Kecederaan Krio Aruhan Tekanan Oksidatif pada Sel Tunjang Hematopoetik Pencilan Sumsum Tulang)

\author{
SHAWAL MARADONA ABDUL WAHAB, ZARIYANTEY ABD HAMID*, \\ RAMYA DEWI MATHIALAGAN \& IZATUS SHIMA TAIB
}

\begin{abstract}
Hematopoietic stem cells (HSCs) transplantation was introduced as curative treatment for various diseases. Cryopreservation of HSCs is crucial for long term storage and maintenance of cellular quality; however, it has been reported that cryopreservation itself causes oxidative stress-driven apoptosis and cell loss. This study investigated impact of supplementing $N$-acetylcysteine $(N A C)$ as antioxidant during cryopreservation on viability and oxidative stress in HSCS. HSCs were isolated from murine bone marrow, cultured in HSCs growth media and cryopreserved $\left(1 \times 10^{6}\right.$ cells per vial) together with $10 \%$ DMSO and NAC (0, 0.25, 0.5 or $2.0 \mu \mathrm{M})$ for $48 \mathrm{~h}, 2$ weeks or 8 weeks at $-196^{\circ} \mathrm{C}$ using controlled-rate-freezing technique. Cell viability and oxidative stress in cryopreserved cells were analysed at each timepoint. Cell viability was significantly reduced $(\mathrm{p}<0.05)$ following cryopreservation as compared to pre-cryopreservation. NAC supplementation significantly increased cell viability $(\mathrm{p}<0.05)$ after $48 \mathrm{~h}$ cryopreservation at $0.5 \mu \mathrm{M}$ and $2.0 \mu \mathrm{M}$ and after 2 weeks cryopreservation at $0.25 \mu \mathrm{M}$ compared to the controls. Cryopreservation significantly enhanced GSH level $(\mathrm{p}<0.05)$ and reduced MDA level $(\mathrm{p}<0.05)$ without affecting SOD activity and PC level in HSCs compared to precryopreservation. NAC supplementation significantly increased GSH level at $0.25 \mu \mathrm{M}$ in cryopreserved HSCs compared to control. In conclusion, NAC supplementation during cryopreservation showed potential in minimizing cryoinjury by promoting cell viability, increasing antioxidant capacity and reducing oxidative damage in HSCs, however these effects are influenced by both durations of cryopreservation and NAC concentration.
\end{abstract}

Keywords: Cryopreservation; hematopoietic stem cells; $N$-acetylcysteine; oxidative stress

ABSTRAK

Pemindahan sel stem hematopoietik (SSH) telah diperkenalkan sebagai rawatan pelbagai penyakit. Pengawetan krio SSH adalah penting untuk penyimpanan dan pemeliharaan kualiti SSH, namun pengawetan krio dilaporkan berupaya mengaruh apoptosis dan penurunan keviabelan sel akibat tekanan oksidatif. Kajian ini telah mengkaji kesan suplementasi $\mathrm{N}$-asetilsistien (NAC) sebagai antioksidan semasa pengawetan krio terhadap keviabelan dan tekanan oksidatif SSH. SSH diisolasi daripada sum-sum tulang mencit, dikulturkan di dalam media pengkulturan SSH dan seterusnya diawet krio ( $1 \times 10^{6}$ sel per vial) dengan penambahan 10\% DMSO dan NAC $(0 \mu \mathrm{M}, 0.25 \mu \mathrm{M}, 0.5 \mu \mathrm{M}$ atau $2.0 \mu \mathrm{M})$ selama 48 jam, 2 minggu atau 8 minggu pada suhu $-196^{\circ} \mathrm{C}$. Keviabelan sel dan tekanan oksidatif ditentukan ke atas SSH pada setiap tempoh pengawetan krio. Keviabelan sel menurun secara signifikan $(\mathrm{p}<0.05)$ selepas pengawetan krio berbanding dengan prapengawetan krio. Suplementasi NAC telah meningkatkan keviabelan sel secara ketara $(\mathrm{p}<0.05)$ selepas pengawetan krio selama 48 jam pada kepekatan $0.5 \mu \mathrm{M}$ dan $2.0 \mu \mathrm{M}$ dan juga selepas 2 minggu pengawetan krio pada kepekatan 0.25 $\mu M$ berbanding kawalan. Pengawetan krio memberi kesan peningkatan aras GSH $(\mathrm{p}<0.05)$ dan penurunan aras MDA $(\mathrm{p}<0.05)$ tanpa memberi kesan yang signifikan terhadap aras SOD dan PC berbanding pra-pengawetan krio. Suplementasi NAC meningkatkan aras GSH secara signifikan $(\mathrm{p}<0.05)$ pada kepekatan $0.25 \mu M$ dalam SSH yang dikrio awet berbanding kawalan. Secara kesimpulannya, suplementasi NAC semasa pengawetan krio berpotensi meningkatkan keviabelan sel dan kapasiti antioksidan serta mengurangkan kesan kerosakan oksidatif, tetapi kesan ini adalah dipengaruhi oleh jangka masa pengawetan krio dan kepekatan NAC yang digunakan.

Kata kunci: $N$-asetilsistien; pengawetan krio; sel stem hematopoietik; tekanan oksidatif

\section{INTRODUCTION}

Hematopoietic stem cells (HSCs) are a group of cells isolated from blood or bone marrow; with pluripotency and self-renewal capacity that allow generation of an entire hematopoietic system ( $\mathrm{Ng} \&$ Alexander 2017).
Pluripotency refers to the capacity of a single HSC to generate multiple types of functional and matured cells (Seita \& Weissman 2010). Hematopoietic stem cell transplantation is a favorable treatment option for diseases of malignant and benign tumors, hematological disorder 
and inherited diseases (Hatzimichael \& Tuthill 2010). The first Malaysian bone marrow-derived HSCs transplantation was performed in University Malaya on a child in 1987; followed by in an adult patient in 1993 (Fadilah et al. 2008). Sources of HSCs for transplantation include bone marrow aspirates, mobilized peripheral blood and umbilical cord blood (Panch et al. 2017). The International Bone Marrow Transplant Registry (IBMTR) reported that after 1998 , it is estimated that $20 \%$ of young patient stem cell transplantation was achieved solely using cord bloodderived HSCs transplantations (Rocha \& Gluckman 2006).

In certain circumstances, cryopreservation of the stem cells is necessary when transplantation cannot be done immediately after stem cell harvest. However, cryopreservation may deleteriously affect the quality and quantity of preserved stem cells in terms of viability and functionality (Pal et al. 2008; Reubinoff et al. 2001; Vosganian et al. 2012). Despite the availability of recommended guidelines for HSCs cryopreservation, a number of limitations associated with the technique of cryopreservation are becoming a major concern. Freezethaw cycle in stem cells causes cellular damages, due to ice nucleation and dehydration. Furthermore, cryopreservation itself induce microtubule depolymerisation in these cells which impairs their ability to maintain a functional spindle after thawing (Tatone et al. 2010). Moreover, cryopreservation may also promote oxidative stress in these cells through osmotic stress and increased reactive oxygen species (ROS) production, all of which reduce the stem cell functionality and increase macromolecule damages such as lipid peroxidation, protein oxidation and DNA damage.

Isolation of HSCs from its bone marrow origin causes changes in stem cell niche. HSCs niche maintenance relies on a few factors including adhesion molecules, cytokines and growth factor, microenvironment oxygen concentration as well as other gene regulators (Matsumoto et al. 2011). HSCs are controlled by a hypoxic microenvironment niche with $\sim 5 \%$ oxygen saturation. However, there is an immediate change in their microenvironment during the isolation procedure, given that ex vivo cultures have normoxic oxygen saturation (Abdul Hamid et al. 2018) that can promote oxidative stress and cause damage to cellular macromolecules; affecting HSCs survivability and functionality (Abdul Hamid et al. 2018; Shaban et al. 2017). To overcome these limitations, the use of antioxidant supplementation is therefore recommended. Antioxidant supplementation prior to cryopreservation is known to reduce oxidative stress and damage. Antioxidants protect cellular constituents from oxidative stress by neutralizing free radicals and terminating the oxidative chain reaction in mitochondrial membrane (Kotahri et al. 2010). They can also help improving cellular survival, potency and differentiation of HSCs (Shaban et al. 2017). N-acetylcysteine (NAC) is an acetylated cysteine residue containing sulphur, commonly used to inhibit ROS-induced cellular damage and apoptosis (Berniakovich et al. 2012). Studies conducted by Abdul Hamid et al.
(2018), Fan et al. (2008) and Liu et al. (2012) all showed that NAC supplementation exhibited significant protective effect in maintaining cultured HSCs in ex vivo condition. Application of NAC to maintain HSCs survival and potency ability following cryopreservation should be investigated to improve the HSCs quality for transplantation use. Hence, this study is conducted to investigate the effect of NAC supplementation on cryopreservation of HSCs by evaluating their viability and oxidative stress markers at different cryopreservation time points of 48 h, 2 weeks and 8 weeks.

\section{MethodS AND MATERIALS}

\section{MATERIALS}

NAC was purchased from Sigma-Aldrich (Sigma Grade, $\geq 99 \%$ (TLC) and was prepared by dissolving powder in phosphate buffer saline (PBS). NAC stock solution was filtered using a filter with pore size $0.22 \mu \mathrm{M}$ under the laminar flow and the working solution was prepared via serial dilutions prior to experiments.

\section{EXPERIMENTAL PROTOCOLS}

All procedures involving the use of laboratory animals was reviewed and approved by UKM Animal Ethics Committee (Ethics Approval Number: FSK/2017/ZARIYANTEY/22NOV./889-NOV.-2017-JULY-2019-AR-CAT2). A total of 15 mice were used throughout the study. HSCs were harvested from bone marrow of ICR mouse as previously described (Boltz-Nitulescu et al. 1987). Briefly, mouse was first sacrificed using cervical dislocation and the stem cells were isolated in complete DMEM medium (supplemented with $10 \%$ fetus bovine serum (FBS) and 2\% Pen-Strep). Cell viability enumeration was measured using Trypan Blue exclusion method. Viable HSCs were cultured in same DMEM medium and cell growth overnight were measured after $24 \mathrm{~h}$ incubation at $37^{\circ} \mathrm{C}$ in $5 \% \mathrm{CO}_{2}$ incubator. Stem cell density for each cryopreservation sample was adjusted to $1 \times 10^{6}$ cells $/ \mathrm{mL}$. For each cryopreservation, $10 \%$ DMSO was added as cryoprotectant and NAC $(0.25,0.5$ and 2.0 $\mu \mathrm{M}$ ) was supplemented accordingly. NAC-free solution was used as vehicle control supplementation (Abdul Hamid et al. 2018). Total volume of suspension in each cryovial was $1.5 \mathrm{~mL}$. The cryovials were frozen using controlledrate-freezing technique inside Planer Kryo 550-16 before storage in liquid nitrogen tank at Pusat Darah Negara (Malaysia). Ambient temperature of the sample was initially lowered to $0^{\circ} \mathrm{C}$ for $5 \mathrm{~min}$ before $-2^{\circ} \mathrm{C}$ reduction per min to $-30^{\circ} \mathrm{C}$, then $-2^{\circ} \mathrm{C}$ reduction per min to $-60^{\circ} \mathrm{C}$ and finally by $-4^{\circ} \mathrm{C}$ reduction per min to $-100^{\circ} \mathrm{C}$ and held at $-100^{\circ} \mathrm{C}$ until the sample was removed and placed in liquid nitrogen tank. Duration of cryopreservation duration was set up at three different time-points i.e. 48 h, 2 weeks and 8 weeks. Upon completion of each cryopreservation time-point, the cryopreserved cells were thawed and resuspended in DMEM medium for viability analysis 
using Trypan Blue exclusion. Cell lysates were prepared from cryopreserved cells for analysis of oxidative stress markers such as glutathione (GSH), superoxide dismutase (SOD), malondialdehyde (MDA) and protein carbonyl (PC), respectively. Each parameter was analyzed using three independent biological replicates.

\section{DETERMINATION OF GLUTATHIONE (GSH) LEVEL AND SUPEROXIDE DISMUTASE (SOD) ACTIVITY}

Following 48 h, 2 weeks and 8 weeks of cryopreservation, cell lysates were prepared and protein level was determined using Bradford assay prior to antioxidant analyses. Level of GSH in cells was measured using spectrophotometer. GSH plays critical roles in protecting cells from oxidative damage and the toxicity of xenobiotic electrophiles. Measurements of SOD activity was based on Beyer and Fridovich (1987). SOD acts as first-line antioxidant defense. In this assay, photon from light source activates riboflavin which oxidizes L-Metionin to generate superoxide and resulting superoxide reacts with SOD enzyme in the sample and lower nitrotetrazolium blue (NBT) reduction. Reduction of NBT causes formation of the purple-colored formazan measurable spectrophotometrically at $560 \mathrm{~nm}$ wavelength.

\section{DETERMINATION OF MALONDIALDEHYDE (MDA) AND PROTEIN CARBONYL (PC) LEVELS}

For MDA assay, cryopreserved cells were collected, lysed and centrifuged at $1000 \mathrm{rpm}$ for $10 \mathrm{~min}$. All the supernatants were collected, and thiobarbituric acid (TBA) reagent was added into each vial containing 100 $\mu \mathrm{L}$ of supernatant samples. All vials were incubated for $60 \mathrm{~min}$ at $95^{\circ} \mathrm{C}$ and were left in room temperature for 10 min. $200 \mu \mathrm{L}$ of supernatant (containing MDA-TBA adduct) was pipetted into 96 wells microtiter plate for analysis and absorbance were measured at $532 \mathrm{~nm}$ wavelength. For protein carbonyl assay, cells were similarly collected, sonicated in $2 \mathrm{~mL}$ of buffer solution and centrifuged at $1000 \mathrm{rpm}$ for $15 \mathrm{~min}$ at $4^{\circ} \mathrm{C} .50 \mu \mathrm{L}$ of supernatant was transferred into microcentrifuge tubes and was added with $50 \mu \mathrm{L}$ trichloroacetic acid (TCA) prior to centrifugation at $1000 \mathrm{rpm}$ for $5 \mathrm{~min}$ at $4^{\circ} \mathrm{C}$. Supernatant were discarded and $500 \mu \mathrm{L}$ dinitrophenylhydrazine (DNPH) was added into each tube and were incubated in dark for $1 \mathrm{~h}$. The tubes were centrifuged again at $1000 \mathrm{rpm}$ for $5 \mathrm{~min}$ at $4^{\circ} \mathrm{C}$. Supernatant was discarded and the cell pellets were resuspended in 1 $\mathrm{mL} 10 \% \mathrm{w} / \mathrm{v}$ TCA. All tubes were put in the ice for $5 \mathrm{~min}$ and centrifuged. All cell pellets were resuspended with 1 $\mathrm{mL} 5 \mathrm{M}$ urea after centrifugation and the tubes were kept in water bath $\left(37^{\circ} \mathrm{C}\right)$ for $15 \mathrm{~min}$. The tubes were centrifuged at $1000 \mathrm{rpm}$ for $5 \mathrm{~min}$ at $4^{\circ} \mathrm{C}$ and $200 \mu \mathrm{L}$ of supernatant were pipetted into 96 wells microtiter plate for measurement of absorbance at $360 \mathrm{~nm}$ wavelength.

\section{STATISTICAL ANALYSIS}

All results are reported as mean \pm standard error of mean (SEM) from three independent experiments. The results were analyzed using one-way analysis of variance (ANOVA) and Tukey's post-hoc test with $p<0.05$ considered as statistically significant.

\section{RESULTS}

\section{EFFECT OF NAC SUPPLEMENTATION IN} CRYOPRESERVATION ON CELL VIABILITY OF HSCS

Analysis of HSCs viability after cryopreservation at temperature of $-196^{\circ} \mathrm{C}$ for $48 \mathrm{~h}, 2$ weeks and 8 weeks was enumerated using trypan blue exclusion method. Cryopreservation at $-196^{\circ} \mathrm{C}$ caused a significant reduction $(p<0.05)$ in cell viability in all experimental groups after 48 h, 2 weeks and 8 weeks as compared to pre-cryopreserved group. However, as shown in Figure 1, supplementation with NAC for 48 h caused a significant increase $(p<0.05)$ in cell viability at $0.5 \mu \mathrm{M}\left(3.6 \pm 0.29 \times 10^{5}\right)$ and $2.0 \mu \mathrm{M}$ $\left(4.07 \pm 0.21 \times 10^{5}\right)$, respectively, as compared to the control group $\left(1.93 \pm 0.12 \times 10^{5}\right)$. After 2 -weeks cryopreservation, a significant increase $(p<0.05)$ in cell viability was only noted between $0.25 \mu \mathrm{M}$ NAC-supplemented group $\left(8.18 \pm 0.14 \times 10^{5}\right)$ and the control group $\left(5.34 \pm 0.12 \times 10^{5}\right)$. Meanwhile, no significant difference in cell viability for all NAC-supplemented groups compared to the control group was observed after 8 weeks cryopreservation.

\section{EFFECT OF NAC SUPPLEMENTATION IN} CRYOPRESERVATION ON GSH LEVEL OF HSCS

Analysis of GSH level in pre-cryopreserved and cryopreserved groups with and without NAC supplementation are shown in Figure 2. The results showed that there is a significant increase $(p<0.05)$ in GSH level for cryopreserved cells without NAC supplementation (control) and cells supplemented with $0.5 \mu \mathrm{M}$ NAC after 48 $\mathrm{h}$ as compared to pre-cryopreservation group (Pre). The level of GSH for control and $0.5 \mu \mathrm{M}$ NAC-supplemented groups was $1.07 \pm 0.09 \mathrm{mmol} / \mathrm{mg}$ and $1.04 \pm 0.003 \mathrm{mmol} /$ $\mathrm{mg}$, respectively, as compared to $0.85 \pm 0.003 \mathrm{mmol} / \mathrm{mg}$ for pre-cryopreservation group. Meanwhile, there is no significant difference in GSH level for cryopreserved cells with NAC at other concentrations $(0.25 \mu \mathrm{M}$ and 2.0 $\mu \mathrm{M})$ as compared to pre-cryopreservation group (Pre). Comparison within cryopreservation groups showed that there was no significant difference in GSH level in cells with NAC-supplemented groups $(0.25 \mu \mathrm{M}, 0.5 \mu \mathrm{M}$ and $2.0 \mu \mathrm{M})$ as compared to control group $(1.07 \pm 0.08 \mathrm{mmol} /$ $\mathrm{mg}$ ). Analysis of HSCs after 2 weeks cryopreservation showed a significant increase $(p<0.05)$ in GSH level for all NAC-supplemented groups including control group compared to pre-cryopreserved group (Pre). The notable GSH levels were $1.54 \pm 0.01 \mathrm{mmol} / \mathrm{mg}$ (control), $1.38 \pm 0.01 \mathrm{mmol} / \mathrm{mg}(0.25 \mu \mathrm{M}), 1.42 \pm 0.00 \mathrm{mmol} / \mathrm{mg}$ $(0.5 \mu \mathrm{M})$ and $1.48 \pm 0.01 \mathrm{mmol} / \mathrm{mg}(2.0 \mu \mathrm{M})$ compared to pre-cryopreservation group $(0.85 \pm 0.003 \mathrm{mmol} / \mathrm{mg})$. However, there is no significant difference in the GSH level of NAC-supplemented cryopreserved HSCs compared 



FIGURE 1. Effect of NAC supplementation on the viability of HSCs after 48 h (A), 2 weeks (B) and 8 weeks $(\mathrm{C})$ cryopreservation. Each data is obtained from three different experiments $(n=3)$. Data is expressed as mean \pm standard error of mean (SEM). a Significant different $(p<0.05)$ against pre-

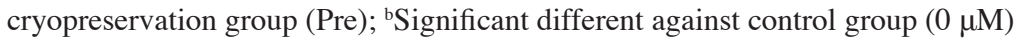
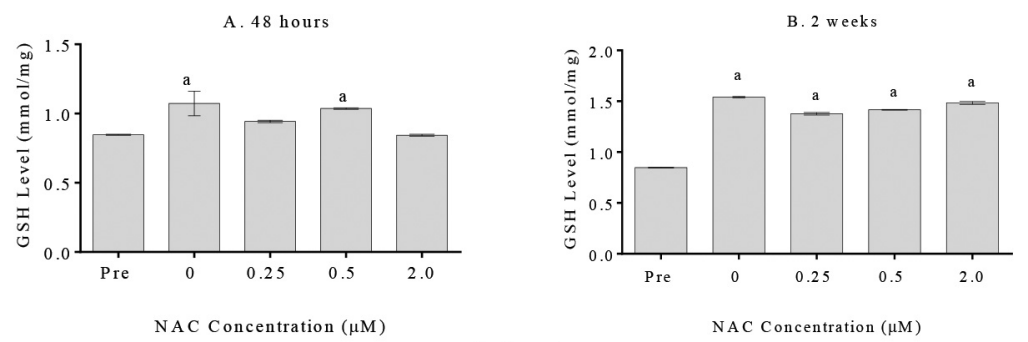

NAC Concentration $(\mu \mathrm{M}) \quad$ NAC Concentration $(\mu \mathrm{M})$

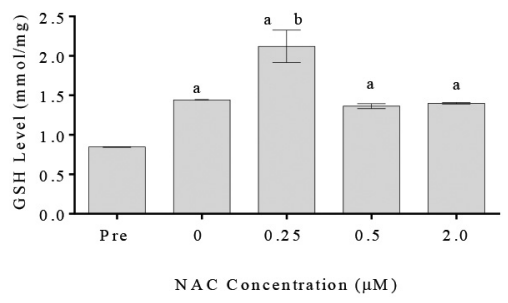

FIGURE 2. Effect of NAC supplementation on the GSH level of HSCs after $48 \mathrm{~h}$ (A), 2 weeks (B) and 8 weeks $(C)$ cryopreservation. Each data is obtained from three different experiments $(n=3)$. Data

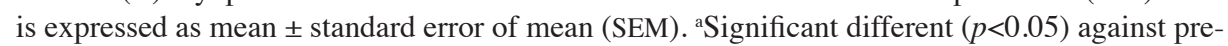



to the control group. Meanwhile, a significant increase $(p<0.05)$ of GSH level were observed after 8 weeks of cryopreservation compared to pre-cryopreserved group. GSH levels were as follows: $1.44 \pm 0.003 \mathrm{mmol} /$ $\mathrm{mg}$ (control), $2.12 \pm 0.2 \mathrm{mmol} / \mathrm{mg}(0.25 \mu \mathrm{M}), 1.40 \pm 0.02$ $\mathrm{mmol} / \mathrm{mg}(0.5 \mu \mathrm{M})$ and $1.4 \pm 0.01 \mathrm{mmol} / \mathrm{mg}(2.0 \mu \mathrm{M})$ compared to pre-cryopreserved group $(0.85 \pm 0.003 \mathrm{mmol} /$ $\mathrm{mg}$ ). However, when comparing the GSH level between NAC-supplemented group against control group during cryopreservation state, a significant increase $(p<0.05)$ of GSH level was only noted at $0.25 \mu \mathrm{M}$ NAC.
EFFECT OF NAC SUPPLEMENTATION IN CRYOPRESERVATION TOWARDS SOD ACTIVITY OF HSCS

After $48 \mathrm{~h}$ cryopreservation, no significant difference was seen in SOD activity between pre-cryopreserved (Pre) and cryopreserved groups; along with no remarkable effect of NAC on GSH levels during cryopreservation state (Figure 3). Similar finding was also noted after 2 weeks cryopreservation with exception for NAC at 0.5 $\mu \mathrm{M}$ which caused significant reduction $(p<0.05)$ of SOD activity $(38 \pm 2.65 \mathrm{U} / \mathrm{min} / \mathrm{mg})$ compared to control group $(76 \pm 6.81 \mathrm{U} / \mathrm{min} / \mathrm{mg})$. Meanwhile, a significant increase 



C. 8 weeks

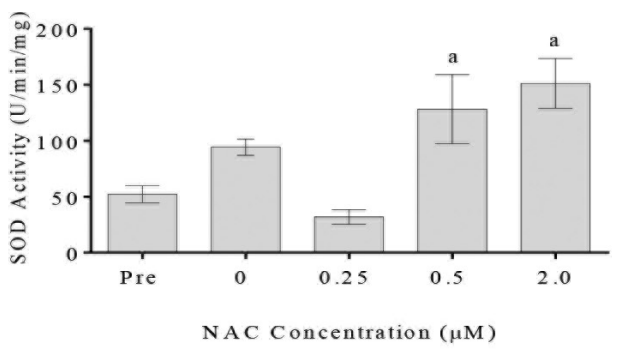

FIGURE 3. Effect of NAC supplementation on the SOD activity of HSCs after $48 \mathrm{~h}$ (A), 2 weeks (B) and 8 weeks $(\mathrm{C})$ cryopreservation. Each data is obtained from three different experiments $(n=3)$. Data

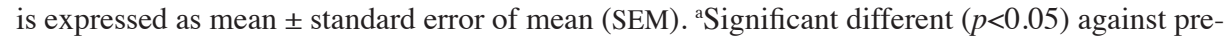
cryopreservation group (Pre); ${ }^{b}$ Significant different against control group $(0 \mu \mathrm{M})$

$(p<0.05)$ in SOD activity for cells cryopreserved in the presence of NAC at $0.5 \mu \mathrm{M}(128 \pm 17.84 \mathrm{U} / \mathrm{min} / \mathrm{mg})$ and $2.0 \mu \mathrm{M}(151 \pm 22.23 \mathrm{U} / \mathrm{min} / \mathrm{mg})$ for 8 weeks was noted as compared to pre-cryopreservation group $(52 \pm 7.53 \mathrm{U} /$ $\mathrm{min} / \mathrm{mg}$ ). However, there was no significant difference in SOD activity between NAC-supplemented groups $(0.25,0.5$ and $2.0 \mu \mathrm{M}$ ) compared to the control group after 8 weeks cryopreservation.

EFFECT OF NAC SUPPLEMENTATION IN CRYOPRESERVATION TOWARDS MDA LEVEL OF HSCS

After $48 \mathrm{~h}$ cryopreservation, there is no significant difference in MDA level between pre-cryopreserved group (Pre) and cryopreserved group for all NAC concentration (Figure 4). There is also no significant difference in MDA level seen at all NAC concentrations $(0.25,0.5$ and $2.0 \mu \mathrm{M})$ compared to the control group after $48 \mathrm{~h}$ cryopreservation. However, a significant reduction $(p<0.05)$ in MDA level between cryopreserved and pre-cryopreservation groups were noted following 2 weeks and 8 weeks cryopreservation; although the effect of NAC on the MDA levels during cryopreservation state at these time-points were not significant. MDA level in pre-cryopreservation group was $7.67 \pm 0.55 \mathrm{nmol} / \mathrm{mg}$; followed by $1.60 \pm 0.10$ $\mathrm{nmol} / \mathrm{g}$ (control), $2.57 \pm 1.11 \mathrm{nmol} / \mathrm{g}(0.25 \mu \mathrm{M}), 4.17 \pm 0.45$ $\mathrm{nmol} / \mathrm{g}(0.5 \mu \mathrm{M})$ and $2.47 \pm 0.74 \mathrm{nmol} / \mathrm{g}(2.0 \mu \mathrm{M})$ after 4 weeks cryopreservation. As for 8 weeks cryopreservation time-point, the measured MDA levels for control and NAC-added groups $(0.25,0.5$ and $2.0 \mu \mathrm{M})$ were $2.43 \pm 0.23$ $\mathrm{nmol} / \mathrm{g}, 1.63 \pm 0.27 \mathrm{nmol} / \mathrm{g}, 4.3 \pm 0.83 \mathrm{nmol} / \mathrm{g}$ and $1.63 \pm 0.26$ $\mathrm{nmol} / \mathrm{g}$, respectively.
EFFECT OF NAC SUPPLEMENTATION IN CRYOPRESERVATION TOWARDS PC LEVEL OF HSCS

A significant increase $(p<0.05)$ in the PC level for cryopreserved cells with and without NAC supplementation compared to pre-cryopreservation group (Pre) after $48 \mathrm{~h}$ of cryopreservation (Figure 5) was noted. Level of PC in pre-cryopreserved group was $4.86 \pm 0.08 \mathrm{nmol} / \mathrm{g}$; while the cryopreserved group recorded PC levels of 5.56 \pm 0.03 $\mathrm{nmol} / \mathrm{g}$ (control), $5.3 \pm 0.06 \mathrm{nmol} / \mathrm{g}(0.25 \mu \mathrm{M}), 5.76 \pm 0.03$ $\mathrm{nmol} / \mathrm{g}(0.5 \mu \mathrm{M})$ and $4.66 \pm 0.03 \mathrm{nmol} / \mathrm{g}(2.0 \mu \mathrm{M})$, respectively. However, there is no significant difference in PC level between cryopreserved HSCs that received NAC supplementation $(0.25,0.5$ and $2.0 \mu \mathrm{M})$ and the control group $(0 \mu \mathrm{M})$.

Analysis on HSCs after 2 weeks cryopreservation showed a significant increase in PC level for HSCs underwent cryopreservation than the HSCs in precryopreservation group (Pre). The PC level for precryopreservation group was $4.86 \pm 0.08 \mathrm{nmol} / \mathrm{mg}$ compared to groups receiving $0.25 \mu \mathrm{M}, 0.5 \mu \mathrm{M}$ and $2.0 \mu \mathrm{M}$ NAC supplementation $(20.70 \pm 0.46 \mathrm{nmol} / \mathrm{g}, 22.50 \pm 1.85 \mathrm{nmol} / \mathrm{g}$ and $21.37 \pm 2.25 \mathrm{nmol} / \mathrm{g}$; respectively) and control group $(21.73 \pm 0.44 \mathrm{nmol} / \mathrm{g})$. No significant difference was seen in PC level within cryopreserved group in between NACsupplemented $(0.25 \mu \mathrm{M}, 0.5 \mu \mathrm{M}$ and $2.0 \mu \mathrm{M})$ and control groups. A significant increase $(p<0.05)$ of PC levels were also noted between 8 weeks cryopreserved HSCs compared to the pre-cryopreserved group (Pre). The levels of PC for cryopreserved HSCs were at $22.27 \pm 1.28 \mathrm{nmol} / \mathrm{g}$ (control), $28.33 \pm 2.87 \mathrm{nmol} / \mathrm{g}(0.25 \mu \mathrm{M}), 22.77 \pm 1.24 \mathrm{nmol} / \mathrm{g}(0.5 \mu \mathrm{M})$ and $17.70 \pm 1.62 \mathrm{nmol} / \mathrm{g}(2.0 \mu \mathrm{M})$ compared to $4.86 \pm 0.08$ $\mathrm{nmol} / \mathrm{g}$ for pre-cryopreservation group. Meanwhile, 

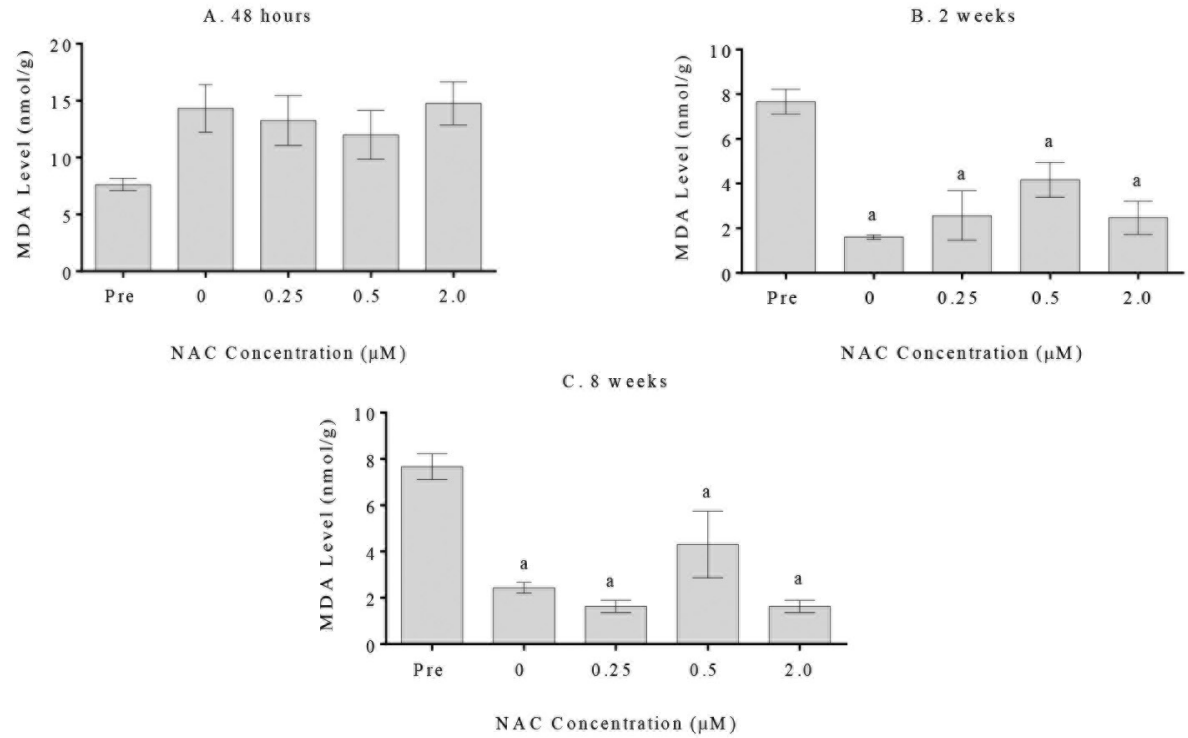

FIGURE 4. Effect of NAC supplementation on the MDA level of HSCs after $48 \mathrm{~h}$ (A), 2 weeks (B) and 8 weeks

(C) cryopreservation. Each data is obtained from three different experiments $(n=3)$. Data is expressed as mean \pm standard error of mean $(\mathrm{SEM}) .{ }^{\mathrm{a} S i g n i f i c a n t ~ d i f f e r e n t ~}(p<0.05)$ against pre-cryopreservation group (Pre)
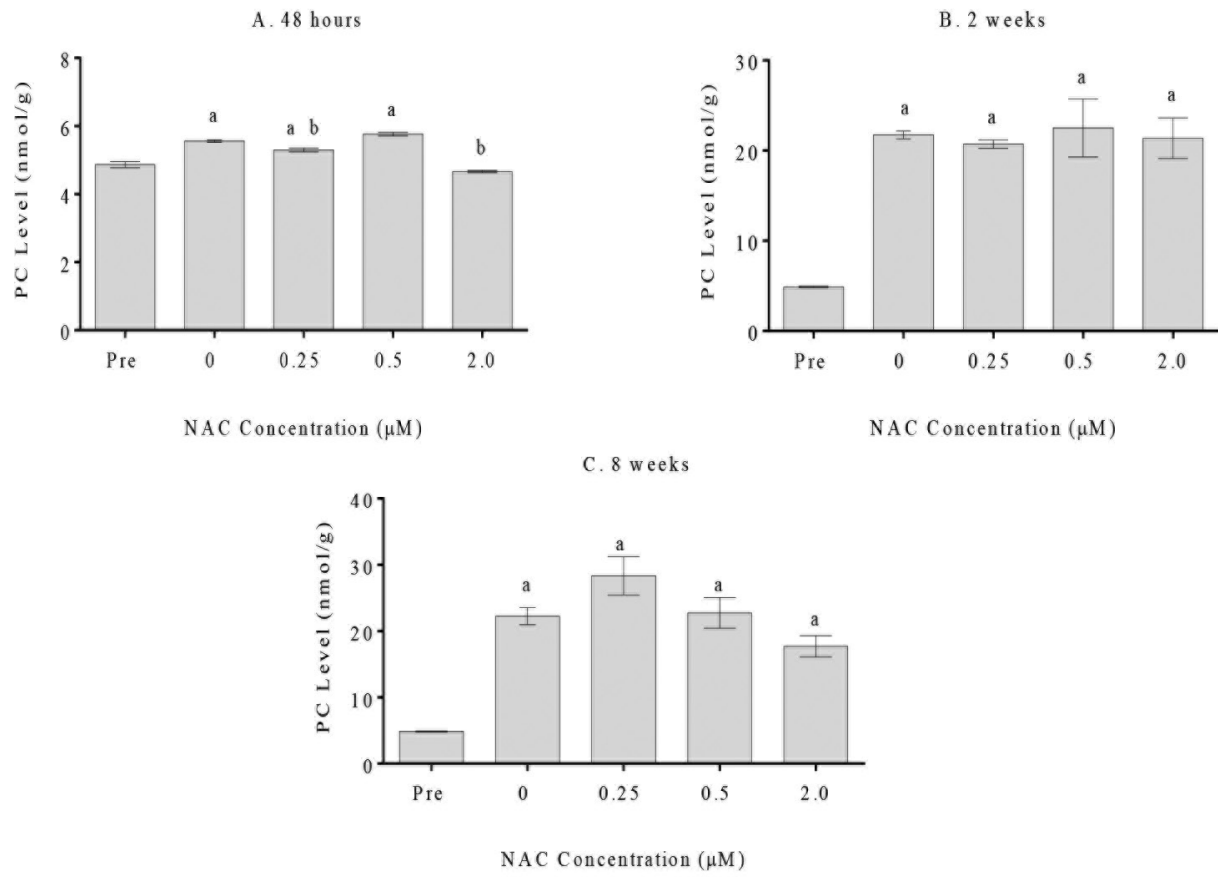

FIGURE 5. Effect of NAC supplementation on the PC level of HSCs after 48 h (A), 2 weeks (B) and 8 weeks (C) cryopreservation. Each data is obtained from three different experiments $(n=3)$. Data is expressed as





there is no significant difference in PC level between NAC supplemented group $(0.25,0.5$ and 2.0$)$ compared to the cryopreserved control group.

\section{DISCUSSION}

Usage of HSCs in clinical transplantation is one of the most favourable treatment options for haematological- related disorders, lymphoid cancers and other variety of disorders (Copelan 2006). Thus, cryopreservation plays an important role in both autologous and allogeneic HSCs transplantation. However, cryopreservation also causes a potential cellular damage to the cryopreserved cells via oxidative stress. This event may affect the cellular viability, the stemness property and the functionality of cells to proliferate and differentiate (Djuwantono et 
al. 2011; Maraldi et al. 2015). Hence, the usage of biooxidant supplements in cryopreservation medium offers an alternative solution to overcome these limitations (Motta et al. 2010). Thus, this study was conducted to investigate the effect of $\mathrm{N}$-acetylcysteine (NAC) supplementation on the cryopreserved HSCs by evaluating cellular viability and oxidative stress after 48 h, 2 weeks and 8 weeks cryopreservation at $-196^{\circ} \mathrm{C}$.

Previously, NAC showed protective effect against oxidative-stress mediated cellular damage during ex vivo maintenance of cultured HSPCs by reducing cell loss, lowering oxidative stress and maintaining the repopulation capacity of HSCs into committed progenitors (Abdul Hamid et al. 2018, 2014; Chin et al. 2018; Liu et al 2012). However, the cryopreservative role of NAC for preservation of HSCs remains unexplored. Since the present study is among the few studies concerning NAC utility for HSCs cryopreservation with incorporation of oxidative stress status, the three time-points were selected at the current stage of the study to identify the time-points effects from hours up to months. There is no standard recommendation for HSCs cryopreservation time-points; although a number of studies reported that the cells can be stored up to years at $-196^{\circ} \mathrm{C}$ (Berz et al. 2007). In term of clinical practices, cryopreservation is recommended when transplantation is not doable within $72 \mathrm{~h}$ from the period of HSCs collection (Berz et al. 2007). However, in the context of research application, the ability to cryopreserve the HSCs without compromising its property is also crucial to allow optimal preservation and to minimize the need for fresh isolation of the sample for every usage. This will improve usability of HSCs for research application.

Based on the results, it was shown that cryopreservation caused a significant loss of cellular viability after 48 h, 2 weeks and 8 weeks for cryopreserved HSCs either with or without NAC. Many studies showed that cryopreservation is responsible for oxidative stress in most eukaryotic cells through cell membrane damage, mitochondrial dysfunction and variations in the oxidative metabolism during the cell survival (Tatone et al. 2010). Hence, it is speculated that the significant cell loss during all three time-points of cryopreservation are due to cell damage and intracellular oxidative stress throughout the preservation. The freezing process in cryopreservation may cause ice formation that damages the cells. At rapid cooling rate, intracellular ice crystals cause mechanical rupture of cell structure. Contrarily, slower rate of freezing causes ice crystal formation in the extracellular space resulting in increased osmolality since free water molecules may be incorporated into the ice crystals. Loss of free water molecules result in hyperosmolality and cell dehydration (Rowley 1992). Formation of ice crystals also leads to oxidative stress in the cells due to mitochondrial injury that disrupts oxidative metabolism in cells. Oxidative stress during cryopreservation additionally might incur from osmotic stress and increased cellular metabolism. Osmotic stress is a condition that causes sudden change in movement of free water across the cell membrane due to difference in osmotic gradient between intracellular and extracellular space. Withdrawal of water molecules causes cells to shrink and rupture. Osmotic stress also activates generation of superoxide anions by activating NADPH oxidase (Orrenius et al. 2007).

This study also showed a significant increase in cell viability in cryopreserved HSCs supplemented with 0.5 $\mu \mathrm{M}$ and $2.0 \mu \mathrm{M}$ NAC compared to control group after 48 $\mathrm{h}$ cryopreservation. This finding is in agreement with a previous study that showed supplementation with NAC at $0.25 \mu \mathrm{M}$ and $0.5 \mu \mathrm{M}$ suppressed cellular ROS levels and improved cell viability (Abdul Hamid et al. 2018). HSCs cryopreserved with $0.25 \mu \mathrm{M}$ NAC also showed a significant increase in cell viability after 2 weeks cryopreservation. Addition of NAC as antioxidant supplement prior to cryopreservation might boost antioxidant system and reduce potential cell damage in HSCs. This finding is also consistent with several established studies that concluded antioxidants can not only mitigate oxidative stress, but also improve stem cell survival and improve their potency and differentiation (Shaban et al. 2017). In a previous study, Roselle supplementation as antioxidant with bonemarrow-derived HSCs induced a significant increase in GSH level and SOD activity in HSCs (Abdul Hamid et al. 2014). $\mathrm{N}$-acetylcysteine is a potent antioxidant due to its ability to scavenge ROS and inhibit cellular damage and apoptosis driven by ROS. However, in this study, NAC was only able to improve cell viability at higher concentrations after 48 $\mathrm{h}$ and 2 weeks cryopreservation. NAC at $0.5 \mu \mathrm{M}$ and 2.0 $\mu \mathrm{M}$ concentration were only efficient in increasing cell viability after short term cryopreservation. At longer term cryopreservation, a higher concentration of NAC is required to reduce cellular damage and minimize excessive ROSdriven oxidative stress. This is in line with findings from a study that reported NAC reduces the rate of chromosomal aberrations in HSCs (Liu et al. 2012) and greater CD34+ cells were harvested from ex vivo culture of cord blood supplemented with NAC (Fan et al. 2008).

To date, most of the reported studies concerning the use of antioxidant as cryopreservative agent are mostly applied for preservation of embryos, spermatozoa and embryonic stem cells (Isachenko et al. 2013; Zhou 2004); with limited reports regarding the preservation of HSCs are available. Previous studies had shown that a combination of the bio-antioxidant catalase and the membrane stabilizer; trehalose in the conventional freezing mixture affords better cryoprotection to hematopoietic progenitor cells (Sasnoor et al.2003) and greater preservation of mice bone marrow cells was achieved in the presence of antioxidant supplements (Limaye 1997). However, the influenced of cryopreservation time-points on the cell recovery postthawed cryopreservation deserve further investigation as no similar study with regards to time-points effect has been reported.

On antioxidant status analysis, this study showed a statistically significant increase in GSH level among cryopreserved hematopoietic stem cells supplemented with NAC after 48 h, 2 weeks and 8 weeks cryopreservation 
compared to the pre-cryopreserved cells. However, there is no significant increase in SOD activities after cryopreservation even with NAC supplementation at all concentrations. This finding is consistent with reports of Abdul Hamid et al. (2018) whereby different HSCsprogenitor cells are suggested to acquire different antioxidant system response in presence of NAC supplementation. Meanwhile, previous report indicated that antioxidant supplementation caused no significant alteration on the GSH level and SOD activity of post-thawed sperm cells (Bucak et al. 2009). The antioxidant system plays an important role in cellular protection against damage and potential oxidative stress. It is also important for development of immune response (Bounous \& Molson 2003). NAC has been used in clinical settings for more than 30 years in treatment and management of HIV infection, cancer and heart disease. Irabbasi et al. (2016) reported that NAC supplementation does not only improve nutritional status among chronic obstructive pulmonary disease (COPD) patients but also increased plasma GSH level by $171 \%$ in these patients. NAC acts as an efficient antioxidant through its ability to reduce extracellular cystine to cysteine as well by acting as source of thiol group (-SH) metabolite. As free-SH source, NAC has ability to enhance endogenous glutathione-S-transferase (GST) activity, promote detoxification and act directly on ROS and prevent cellular oxidation (Kelly 1998). The significant increase in GSH level after NAC supplementation in cryopreserved HSCs in this study implies that NAC could acts as a precursor for intracellular GSH biosynthesis (Samuni et al. 2013). Hence, it is possible that due to high concentration of hydroperoxides generated after cryopreservation, a compensatory mechanism may have triggered the increase in GSH level in HSCs to facilitate ROS detoxification and reduce oxidative damage.

The presence of intracellular Ros due to cryopreservation may cause cellular damage and disrupt cellular macromolecules through DNA damage, protein oxidation and lipid peroxidation as previously mentioned. Therefore, oxidative stress markers including MDA and PC were measured in this study. PC can be produced through oxidative cleavage of proteins by either $\alpha$-amidation pathway or by oxidation of glutamyl side chains leading to formation of a peptide in which the N-terminal amino acid is blocked by an $\alpha$-ketoacyl derivatives (Dalle-donne et al. 2003). Carbonyl group can also be introduced into protein by secondary reaction of the nucleophilic side chains of cysteine, histamine and lysine residues together with aldehyde molecules such as 4-hydroxy2-nonenal, malondialdehyde and 2-propenal produced during lipid peroxidation. PC level in cryopreserved cells was significantly increased both in presence or absence of NAC supplementation after 48 h, 2 weeks and 8 weeks cryopreservation, respectively, compared to the pre-cryopreservation group. This indicated that NAC had no effect in reducing protein oxidation caused by cryopreservation. Hence, the NAC supplementation is incapable of preventing or reducing formation of carbonyl group caused by the protein oxidation.
Meanwhile, this study also showed a significant reduction in MDA level in cryopreserved cells supplemented with NAC after 2 weeks and 8 weeks cryopreservation as compared to pre-cryopreserved cells. MDA is generated from the ROS-driven cellular lipid peroxidation whereby lipid peroxidation can disrupt the membrane lipid bilayer arrangement and may inactivate membranebound receptors and enzymes as well as increase tissue permeability (Birben et al. 2012). Hydroxyl (HO•) and hydroperoxyl $\left(\mathrm{HO}_{2}\right)$ radicals are the most prevalent type of ROS with ability to cause lipid peroxidation. These hydroperoxides however can be decomposed through two-electron reduction by glutathione peroxidase. Hence, this explained the increase in level of intracellular GSH as discussed earlier as compensatory response to redox signalling reaction towards lipid peroxidation. Generation of MDA from lipid peroxidation inactivates numerous cellular proteins by forming protein crosslinkages. An effective antioxidant system is required for reducing such damages, and supplementation with NAC in this study has helped to increase the GSH level. In this study, reduced level of MDA observed after 2 and 8 weeks cryopreservation suggested that NAC might help in reducing MDA level via lipid peroxidation chain inhibition after long term but fails to inhibit such reaction at short term cryopreservation (48 h).

The ability of NAC to reduce oxidative damage on stem cells in various experimental studies has been documented with most of the reported studies are largely based on in vitro observation (Shaban et al. 2007). Fatima et al. (2017) reported that NAC abrogated $\mathrm{H}_{2} \mathrm{O}_{2}$ induced oxidative-stress of Wharton's Jelly (WJ) derived Mesenchymal stem cells (WJ-MSCs) by restoring the activity of GSH, SOD and CAT, along with reduced level of MDA. Previous studies have also shown that NAC able to protect oxidative injury mediated by $\mathrm{H}_{2} \mathrm{O}_{2}$ on diabetic mouse derived mesenchymal stem cells (Ali et al. 2016) and germ cells (Maheshwari et al. 2011) as well as able to decrease oxidative stress, rescue the decline in cellular properties induced by long-term in vitro culture and promote hematopoietic differentiation of induced pluripotent stem cells (iPSCs) (Berniakovich et al. 2012). Recently, studies also reported that NAC supplementation able to protects dental tissue stem cells against oxidative stress in vitro (Martacic et al. 2018) and reduced oxidative stress markers (MDA and $\mathrm{PC}$ ) in cisplatin - induced toxicity in rat brain (Abdel-Wahab \& Moussa 2019). Despite of these reports, the cryoprotective effect of NAC specific for HSCs cryopreservation at differential time points concerning the qualitative and quantitative outputs has not been fully elucidated. Thus, the findings from present study could provide additional information concerning the role of NAC for HSCs cryopreservation that can potentially improve the cryopreservation approach.

\section{CONCLUSION}

Overall, it can be concluded that cryopreservation impaired the viability and promote greater protein oxidation (PC). 
NAC showed potential to improve cell viability and improved antioxidant capacity (GSH); all of which are influenced by the cryopreservation's time-point and NAC concentrations. Further study is required to establish the conclusion.

\section{ACKNOWLEDGEMENTS}

This study is supported by FRGS (UKM) FRGS/1/2016/ SKK13/UKM/03/1. The authors would like to thank Cellular Therapy Division of Pusat Darah Negara and Bioserasi Laboratory, UKM for providing assistance for this research.

\section{REFERENCES}

Abdel-Wahab, W.M. \& Moussa, F.I. 2019. Neuroprotective effect of $\mathrm{N}$-acetylcysteine against cisplatin-induced toxicity in rat brain by modulation of oxidative stress and inflammation. Drug Des. Devel. Ther. 11(13): 1155-1162.

Ali, F., Khan, M., Khan, S.N. \& Riazuddin, S. 2016. N-Acetyl cysteine protects diabetic mouse derived mesenchymal stem cells from hydrogen-peroxide-induced injury: A novel hypothesis for autologous stem cell transplantation. J. Chin. Med. Assoc. 79(3): 122-129.

Abdul Hamid, Z., Hii, W., Lin, L., Abdalla, B.J., Yuen, O.B., Latif, E.S., Mohamed, J., Nor Fadilah, R., Wah, C.P., Muhd Khairul Akmal, W.H. \& Siti Balkis, B. 2014. The role of Hibiscus sabdariffa L. (Roselle) in maintenance of ex vivo murine bone marrow-derived hematopoietic stem cells. The Scientific World Journal 2014: 258192.

Abdul Hamid, Z., Tan, H.Y., Chow, P.W., Harto, K.A.W., Chan, C.Y. \& Mohamed, J. 2018. The role of N-acetylcysteine supplementation on the oxidative stress levels, genotoxicity and lineage commitment potential of ex vivo murine haematopoietic stem/progenitor cells. Sultan Qaboos University Medical Journal 18(5): 130-136.

Berniakovich, I., Laricchia-Robbio, L., Carlos, J. \& Izpisua Belmonte, J.C. 2012. N-acetylcysteine protects induced pluripotent stem cells from in vitro stress: Impact on differentiation outcome. Int. J. Dev. Biol. 56(9): 729-735.

Berz, D., McCormack, E.M., Winer, E.S., Colvin, G.A. \& Quesenberry, P.J. 2017. Cryopreservation of hematopoietic stem cells. American Journal of Hematology 82(6): 463-472.

Birben, E., Sahiner, U.M., Sackesen, C., Erzurum, S. \& Kalayci, O. 2012. Oxidative stress and antioxidant defense. World Allergy Organization Journal 5(1): 9-19.

Boltz-Nitulescu, G., Wiltschke, C., Holzinger, C., Fellinger, A., Scheiner, O., Gessl, A. \& Förster, O. 1987. Differentiation of rat bone marrow cells into macrophages under the influence of mouse L929 cell supernatant. Journal of Leukocyte Biology 41(1): 83-91

Bounous, G. \& Molson, H.J. 2003. The antioxidant system. Anticancer Research 23: 1411-1416.

Bucak, M.N., Sarı̈zkan, S., Tuncer, P.B., Ulutaş, P.A. \& Akçadağ, H.İ. 2009. Effect of antioxidants on microscopic semen parameters, lipid peroxidation and antioxidant activities in Angora goat semen following cryopreservation. Small Ruminant Research 81: 90-95.

Copelan, E.A. 2006. Hematopoietic stem-cell transplantation. The New England Journal of Medicine 354(17): 1813-1826.

Chin, Y.C., Abdul Hamid, Z., Taib, I.S., Hui, T., Muhd Khairul Akmal,W.H. \& Chow, P.W. 2018. Effects of n-acetyl-cysteine supplementation on ex vivo clonogenicity and oxidative profile of lineage-committed hematopoietic stem cells. Jurnal Teknologi DOI: https://doi.org/10.11113/jt.v80.11419.

Dalle-donne, I., Rossi, R., Giustarini, D., Milzani,A . \& Colombo, R. 2003. Protein carbonyl groups as biomarkers of oxidative stress. Clinica Chimica Acta 329: 23-38.

Djuwantono, T., Wirakusumah, F.F., Achmad, T.H., Sandra, F., Halim, D. \& Faried, A.A. 2011. Comparison of cryopreservation methods: Slow-cooling vs rapid-cooling based on cell viability, oxidative stress, apoptosis, and CD34+ enumeration of human umbilical cord blood mononucleated cells. BMC Research Notes 4: 371.

Fadilah, S.A.W., Leong, C.F. \& Cheong, S.K. 2008. Stem cell transplantation in Malaysia and future directions. Medical Journal Malaysia 63(4): 279-280.

Fan, J., Cai, H., Yang, S., Yan, L. \& Tan, W. 2008. Comparison between the effects of normoxia and hypoxia on antioxidant enzymes and glutathione redox state in ex vivo culture of CD34 + cells. Comparative Biochemistry and Physiology, Part B 151: 153-158

Fatima, A., Rehman Qadir, A.U., Fatima, N. \& Wajid, N. 2017. The effect of $\mathrm{N}$-acetyl cysteine on $\mathrm{H} 2 \mathrm{O} 2$ mediated oxidative stress in Wharton's jelly derived mesenchymal stem cells. Adv. Life Sci. 4(4): 137-142.

Hatzimichael, E. \& Tuthill, M. 2010. Hematopoietic stem cell transplantation. Stem Cell and Cloning: Advances and Applications 3: 105-117.

Isachenko, E., Isachenko, V., Katkov, I.I., Dessole, S. \& Nawroth, F. 2013. Vitrification of mammalian spermatozoa in the absence of cryoprotectants: From past practical difficulties to present success. Reproductive Biomedicine Online 6: 191-200.

Irabbasi, E.P., Hahar, S.S., Anaf, Z.A.M., Ajab, N.F.R. \& Anap, R.A.M. 2016. Efficacy of ascorbic acid (Vitamin C) and/nacetylcysteine (NAC) supplementation on nutritional and antioxidant status of male Chronic Obstructive Pulmonary Disease (COPD) patients. Journal of Nutritional Science and Vitaminology 62: 54-61.

Kelly, S.G. 1998. Clinical applications of n-acetylcysteine Alternative Medicine Review 3(2): 114-127.

Kotahri, S., Thompson, A., Agarwal, A. \& du Plessis, S.S. 2010 Free radicals: Their beneficial and detrimental effects on sperm function. Indian Journal of Experimental Biology 48(5): 425-435.

Liu, A.M., Qu, W.W., Liu, X. \& Qu, C. 2012. Chromosomal instability in in vitro cultured mouse hematopoietic cells associated with oxidative stress. Aerican Journal of Blood Research 2(1): 71-76.

Limaye, L.S. 1997. Bone marrow cryopreservation: Improved recovery due to bioantioxidant additives in the freezing solution. Stem Cells 15: 353-358.

Maheshwari, A., Misro, M.M., Aggarwal, A., Sharma, R.K. \& Nandan, D. 2011. N-acetyl-L-cysteine counteracts oxidative stress and prevents $\mathrm{H}_{2} \mathrm{O}_{2}$ induced germ cell apoptosis through down-regulation of caspase-9 and JNK/c-Jun. Mol Reprod Dev 78(2): 69-79.

Maraldi, T., Angeloni, C., Giannoni, E. \& Sell, C. 2015. Reactive oxygen species in stem cells. Oxid. Med. Cell Longev. 2015: 159080

Martacic, J., Kovacevic, M., Suncica, F., Zorica, B., Tamara, C. \& Arsic, P.A. 2018. N-acetyl-l-cysteine protects dental tissue stem cells against oxidative stress in vitro. Clinical Oral Investigations 22(8): 2897-2903. 
Matsumoto, Y., Iwasaki, H. \& Suda, T. 2011. Maintenance of adult stem cells: Role of the stem cell niche. In Adult Stem Cells: Stem Cell Biology and Regenerative Medicine, edited by Phinney, D. Totowa: Humana Press. pp. 35-55.

Motta, J.P.R., Gomes, B.E., Bouzas, L.F., ParaguassuBraga, F.H. \& Porto, L.C. 2010. Evaluations of bioantioxidants in cryopreservation of umbilical cord blood using natural cryoprotectants and low concentrations of dimethylsulfoxide. Cryobiology 60: 301-307.

Ng, A.P. \& Alexander, W.S. 2017. Haematopoietic stem cells: Past, present and future. Cell Death Discovery 3: 17002.

Orrenius, S., Gogvadze, V.\& Zhivotovsky, B. 2007. Mitochondrial oxidative stress: Implications for cell death. Annual Review of Pharmacology and Toxicology 47(1): 143-183.

Pal, R., Hanwate, M. \& Totey, S.M. 2008. Effect of holding time, temperature and different parenteral solutions on viability and functionality of adult bone marrow-derived mesenchymal stem cells before transplantation. Journal of Tissue Engineering and Regenerative Medicine 2(7): 436-444.

Panch, S.R., Szymanski, J., Savani, B.N. \& Stroncek, D.F. 2017. Sources of hematopoietic stem and progenitor cells and methods to optimize yields for clinical cell therapy. Biology of Blood and Marrow Transplantation 23(8): 1241-1249.

Reubinoff, B.E., Pera, M.F., Vajta, G. \& Trounson, A.O. 2001. Effective cryopreservation of human embryonic stem cells by open pulled straw vitrification method. Human Reproduction 16(10): 2187-2194.

Rocha, V. \& Gluckman, E. 2006. Clinical use of umbilical cord blood hematopoietic stem cells. Biology of Blood and Marrow Transplantation 12(1): 34-41.

Rowley, S.D. 1992. Hematopoietic stem cell cryopreservation: A review of current techniques. Journal of Hematotherapy 250(1): 233-250.

Samuni, Y., Goldstein, S., Dean, O.M. \& Berk, M. 2013. The chemistry and biological activities of $\mathrm{N}$-acetylcysteine. Biochim. Biophys. Acta 1830(8): 4117-4129.
Sasnoor, L.M., Kale, V.P. \& Limaye, L. 2003. Supplementation of conventional freezing medium with a combination of catalase and trehalose results in better protection of surface molecules and functionality of hematopoietic cells. Journal of Hematotherapy \& Stem Cell Research 12: 553-564.

Seita, J. \& Weissman, I.L. 2010. Hematopoietic stem cell: Selfrenewal versus differentiation. Wiley Interdisipline Review Systems Biology and Medicine 2(6): 640-653.

Shaban, S., El-husseny, M.W.A., Abushouk, A.I., Muhammad, A., Salem, A., Mamdouh, M. \& Abdel-daim, M.M. 2017. Effects of antioxidant supplements on the survival and differentiation of stem cells. Oxidative Medicine and Cellular Longevity 13: 1-16.

Tatone, C., Di Emidio, G., Vento, M., Ciriminna, R. \& Artini, P.G. 2010. Cryopreservation and oxidative stress in reproductive cells. Gynecological Endocrinology 26(8): 563-567.

Vosganian, G.S., Waalen, J., Kim, K., Jhatakia, S., Schram, E., Lee, T., Riddell, D. \& James, R.M. 2012. Effects of longterm cryopreservation on peripheral blood progenitor cells. Cytotherapy 14(10): 1228-1234.

Zhou, C.Q. 2004. Cryopreservation of human embryonic stem cells by vitrification. Chin. Med.J.(Engl) 117: 1050-1055.

Biomedical Science Programme, Centre for Health \& Applied Sciences

Faculty of Health Sciences

Universiti Kebangsaan Malaysia

Jalan Raja Abdul Muda Aziz

50300 Kuala Lumpur, Federal Territory

Malaysia

*Corresponding author; email: zyantey@ukm.edu.my

Received: 18 February 2019

Accepted: 19 June 2019 